\title{
Nitric oxide synthase isoforms in the rat uterus: differential regulation during pregnancy and labour
}

\author{
Y-L. Dong, P. R. R. Gangula and C. Yallampalli \\ Department of Obstetrics and Gynecology, The University of Texas Medical Branch, Galveston, \\ TX 77555-1062, USA
}

\begin{abstract}
Production of nitric oxide in the uterus is increased during pregnancy and decreased during delivery. In this study the isoform of nitric oxide synthase which may be responsible for the changes in nitric oxide production was investigated in relation to pregnancy and delivery. Monoclonal antibodies were used to measure changes in neuronal nitric oxide synthase (NOS I), macrophage nitric oxide synthase (NOS II) and endothelial cell nitric oxide synthase (NOS III) protein in the rat uterus by densitometric scanning of specific bands. Results show that: (1) NOS II protein concentrations in the uterus were substantially increased during pregnancy and were decreased during delivery, both at term and preterm (induced by RU486); (2) NOS III protein was present at all stages examined but the concentrations were unchanged; (3) NOS I was present in the rat uterus during the nonpregnant stage but not during pregnancy and delivery. The changes in uterine NOS II protein concentrations during pregnancy and delivery were further confirmed by the changes in the $\mathrm{Ca}^{2+}$-independent, but not $\mathrm{Ca}^{2+}$-dependent, nitric oxide synthase activity. Therefore, an increase in NOS II, thus in nitric oxide production during pregnancy, may play a role in maintaining uterine quiescence.
\end{abstract}

\section{Introduction}

Nitric oxide (NO) is a multifunctional molecule that mediates a number of diverse physiological processes, including vasodilation, neurotransmission, and platelet antiaggregation (Moncada et al., 1991). Relaxation of smooth muscle by nitrovasodilators is thought to be mediated by the increase of guanosine $3^{\prime}, 5^{\prime}$-cyclic monophosphate (cGMP) in smooth muscle cells (Jackson and Busse, 1991). We have recently demonstrated that $\mathrm{NO}$ is a myometrial relaxant and proposed that NO, generated in the gravid uterus, plays a role in maintaining uterine quiescence during pregnancy. Studies from our laboratory (Yallampalli et al., 1993, 1994a, b) and others (Natuzzi et al., 1993; Sladek et al., 1993) provide strong evidence that NO generation is upregulated during pregnancy and downregulated during delivery and postpartum. In rats, we have demonstrated that the production of $\mathrm{NO}$, measured as total nitrites, is increased during mid-gestation and is markedly decreased during spontaneous delivery and postpartum (Yallampalli et al., 1994a). Others have also reported a decrease in nitric oxide synthase (NOS) activity in rat (Natuzzi et al., 1993) and rabbit (Sladek et al., 1993) uterine tissues at term. An increase in NOS content in the uterus may also be important in the maintenance of pregnancy, and a decrease in NOS content in this tissue at term may play a role in initiation of labour.

The NOS isoforms share a common overall catalytic scheme for the oxidation of L-arginine to form NO and L-citrulline and can be divided into two functional classes based on the

Received 12 December 1995. dependence of calcium for activity (Moncada et al., 1991). The cytokine inducible isoform, NOS II, binds calmodulin tightly and its activity is $\mathrm{Ca}^{2+}$-independent. The constitutive forms, NOS I and NOS III, bind calmodulin in a reversible and $\mathrm{Ca}^{2+}$-dependent manner. Although all three isoforms of NOS show a considerable degree (overall $50 \%$ ) of similarity (Sessa, 1994), these proteins can be readily identified by their molecular size, antigenicity and their dependency on $\mathrm{Ca}^{2+}$ for activity.

In the present studies, the rat uterus was examined for the types of isoforms of NOS by western blotting using isoformspecific monoclonal antibodies and by NOS activity. Further, the pregnancy-associated changes in different isoforms in the uterus were characterized to ascertain the isoform(s) involved in the changes we observed in the NO production (Yallampalli et al., 1994a). All three isoforms are present in the rat uterus and changes in NOS II may be responsible for the changes in NO production by the uterus during pregnancy.

\section{Materials and Methods}

\section{Animals}

Pregnant and nonpregnant (adult cycling, 180-200 g body weight; prepubertal, $60 \mathrm{~g}$ body weight) Sprague-Dawley rats were purchased from Harlan Sprague-Dawley (Houston, TX) and were maintained on a $12 \mathrm{~h}$ light:12 h dark schedule. Six rats were used in each group. Normal duration of gestation for rats is 22 days. Pregnant animals were killed in a $\mathrm{CO}_{2}$ inhalation 
chamber either on day 18 of gestation (day 1 of gestation being day of a sperm positive vaginal smear), at the time of spontaneous delivery at term ( $1-3$ pups delivered) or on day 1 postpartum. In a separate experiment, preterm delivery in six pregnant animals was induced by intraperitoneal injection of an antiprogestin, RU486 (Biomol, Plymouth Meeting, PA, $10 \mathrm{mg}$ per rat in mineral oil). This treatment, given on day 17 of gestation, induced preterm delivery on day 18. RU486-induced labour has been extensively used as a model of preterm labour and this model was used in this study. The nonpregnant animals during dioestrus and prepubertal rats at 24 days old were also killed in a $\mathrm{CO}_{2}$ inhalation chamber. The uteri from all animals were removed immediately, cleaned and quickly frozen in liquid nitrogen and stored at $-70^{\circ} \mathrm{C}$ until used.

\section{Tissue homogenization and preparation of subcellular fractions}

Full thickness uterine tissues were homogenized in $50 \mathrm{mmol}$ Tris $\mathrm{l}^{-1}$ buffer ( $\mathrm{pH} \mathrm{7.4)}$ ) containing $0.1 \mathrm{mmol}$ EGTA $\mathrm{I}^{-1}$, $0.14 \mu \mathrm{l} \beta$-mercaptoethanol $\mathrm{ml}^{-1}, 100 \mathrm{mmol}$ phenylmethanesulfonyl fluoride (PMSF) $1^{-1}$ and $0.2 \mathrm{mg}$ trypsin inhibitor $\mathrm{ml}^{-1}$. The homogenate was centrifuged at $1000 \mathrm{~g}$ for $15 \mathrm{~min}$ at $4^{\circ} \mathrm{C}$ and the supernatant was centrifuged at $102000 \mathrm{~g}$ for $30 \mathrm{~min}$ at $4^{\circ} \mathrm{C}$. The supernatant (cytosolic fraction) was decanted from the pellet and the pellet (membranous faction) was resuspended in buffer. The concentration of proteins in all subcellular fractions was measured with the BCA kit (Pierce, Rockford, IL). As positive controls for different isoforms of NOS, proteins obtained from cytosolic fractions of rat cerebellum (NOS I) and cytokine stimulated RAW264.7 cells (NOS II) and membrane fraction of human endothelial cells (NOS III) were used.

\section{Western blotting}

Equal amounts of protein $(30 \mu \mathrm{g})$ were size fractionated on $7.5 \%(\mathrm{w} / \mathrm{v})$ sodium dodecyl sulfate-polyacrylamide gel electrophoresis (SDS-PAGE) and transferred onto a polyvinylidene difluoride (PVDF) membrane. The blots were allowed to dry in air and were then placed in blocking buffer $(1 \%(w / v)$ BSA in $10 \mathrm{mmol}$ Tris buffer $\mathrm{l}^{-1}$ with $100 \mathrm{mmol} \mathrm{NaCl} \mathrm{I}^{-1}, 0.1 \%(\mathrm{v} / \mathrm{v})$ Tween-20, $\mathrm{pH} 7.5$ ) for $1 \mathrm{~h}$ at room temperature. The blots were then incubated with specific primary antibodies for $1 \mathrm{~h}$ at room temperature. All the primary antibodies were monoclonal, obtained from Transduction Laboratories (Lexington, KY) and were used at different final dilutions (NOS I: 1:1000; NOS II: 1:1000; NOS III: 1:500 (v/v)) in the blocking buffer. These antibodies were raised using the following NOS proteins as immunogens: NOS I, a $22.3 \mathrm{kDa}$ protein fragment corresponding to amino acids 1095-1289 of human NOS I; NOS II, a $21 \mathrm{kDa}$ protein fragment corresponding to residues 961-1144 of mouse NOS II; NOS III, a $20.4 \mathrm{kDa}$ protein fragment corresponding to amino acids 1030-1209 of human NOS III. The blots were washed three times for $30 \mathrm{~min}$ each with wash

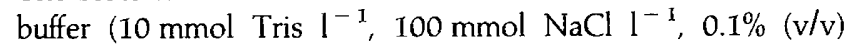
Tween-20, $\mathrm{pH} 7.5$ ) and then incubated with horseradish peroxidase-conjugated goat-antimouse immunoglobulin antibody (Transduction Laboratories) diluted in $5 \%(\mathrm{w} / \mathrm{v})$ non-fat milk in wash buffer. The membranes were washed with wash buffer three times for $30 \mathrm{~min}$ and the enhanced chemiluminescence reagent, ECL kit (Amersham, Arlington Heights, IL) was added and incubated for $1 \mathrm{~min}$ at room temperature. The blots were exposed to autoradiographic film and the intensity of specific immunoreactive bands was quantified using densitometric scanning. Densitometric units of specific protein bands are expressed relative to the values from nonpregnant animals (North et al., 1994). Both the elimination of primary antibodies and the use of a non-NOS related monoclonal antibody indicated the specificity of the NOS protein bands at appropriate molecular sizes (data not shown). In each blot at least one lane was loaded with protein from an appropriate positive control.

\section{Nitric oxide synthase activity}

NOS activity in the uterine homogenate was determined by monitoring the formation of $\left[{ }^{3} \mathrm{H}\right] \mathrm{L}$-citrulline from $\left[{ }^{3} \mathrm{H}\right] \mathrm{L}$-arginine as described by Bush et al. (1992). Briefly, NOS reaction was performed in duplicate for $45 \mathrm{~min}$ at $37^{\circ} \mathrm{C}$ in $200 \mu \mathrm{l}$ buffer containing $2.5 \mathrm{mg} \mathrm{ml}$ protein ${ }^{-1}, 20 \mu \mathrm{mol} \mathrm{FAD,} 4 \mu \mathrm{mol}$ tetrahydrobiopterin $\mathrm{l}^{-1}, 50$ in calmodulin, $1 \mu \mathrm{mol} \mathrm{L}$-arginine $\mathrm{l}^{-1}$, $10 \mathrm{nmol}\left[{ }^{3} \mathrm{H}\right] \mathrm{L}$-arginine and with or without $1 \mathrm{mmol} \mathrm{NADPH}$ $1^{-1}$ and with $1.25 \mathrm{mmol} \mathrm{CaCl}_{2} \mathrm{l}^{-1}$ or with 1 mmol EGTA l ${ }^{-1}$. All reactions were stopped by dilution with ice-cold Hepes buffer (80 mmol Hepes $\mathrm{l}^{-1}, 8 \mathrm{mmol}$ EDTA $^{-1}$, pH 5.2). $\left[{ }^{3} \mathrm{H}\right] \mathrm{L}$-citrulline product was separated from $\left[{ }^{3} \mathrm{H}\right] \mathrm{L}$-arginine by DOWEX (AG 50W-8) cation exchange (Brown et al., 1992). With this method DOWEX retained $96 \pm 2 \%$ of $\left[{ }^{3} \mathrm{H}\right] \mathrm{L}$-arginine. $\left[{ }^{3} \mathrm{H}\right] \mathrm{L}$-arginine was incubated without protein and the resulting counts were subtracted from $\left[{ }^{3} \mathrm{H}\right] \mathrm{L}$-citrulline product counts of each replicate tube. Since NOS activity is NADPH dependent (Marletta, 1993), the activity in the absence of NADPH was subtracted from total activity and the results are expressed as NADPH-dependent activity. NOS activity is expressed as fmol L-citrulline $\mathrm{mg}_{\text {protein }}{ }^{-1} \mathrm{~min}^{-1}$.

\section{Statistical analysis}

One-way ANOVA or Student's t test was used to evaluate differences between various treatments and the differences were assumed significant at $P<0.05$.

\section{Results}

\section{NOS I}

The NOS I antibody reacted with $155 \mathrm{kDa}$ protein from the cytosolic fraction of the rat cerebellum corresponding to NOS I (Fig. 1). The cytosolic fraction from the uterus of nonpregnant rats showed a specific band of $155 \mathrm{kDa}$ that corresponds to NOS I. Densitometric analysis of this band from six animals shows that the NOS I was minimal during pregnancy, delivery and postpartum (Table 1 ). The NOS I is present in the uterus of not only cyclic nonpregnant rats but also noncyclic prepubertal rats (Fig. 2). There were no apparent changes in NOS I content of pregnant uterus during delivery induced by antiprogesterone, RU486. 


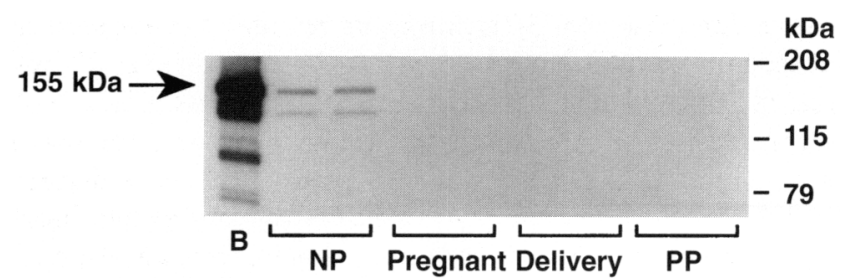

Fig. 1. Western blotting using a monoclonal antibody against nitric oxide synthase I from two representative nonpregnant rats at dioestrus stage (NP), and pregnant rats on day 18 of gestation, during delivery, or on day 1 postpartum (PP). B: rat cerebellum. The antibody reacted with a protein band at $155 \mathrm{kDa}$. Note that this $155 \mathrm{kDa}$ band is present only in the nonpregnant rat uterus.

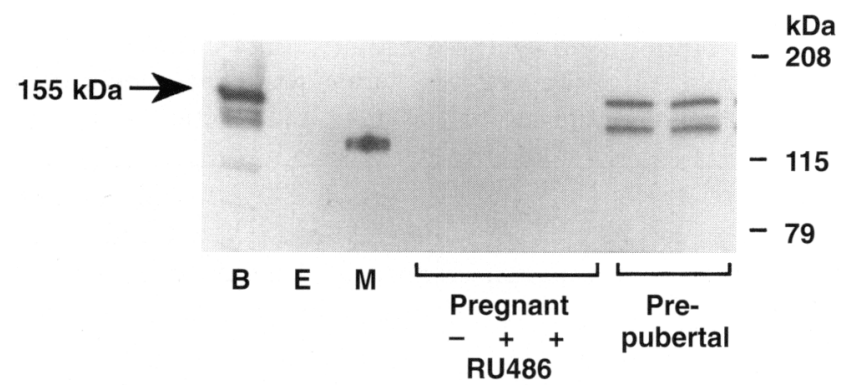

Fig. 2. Western immunoblotting for nitric oxide synthase I in various tissues; rat cerebellum (B), uterus of rats on day 18 of gestation with or without administration of antiprogesterone, RU486, and of prepubertal rats, E: human endothelial cells; M: mouse macrophages.

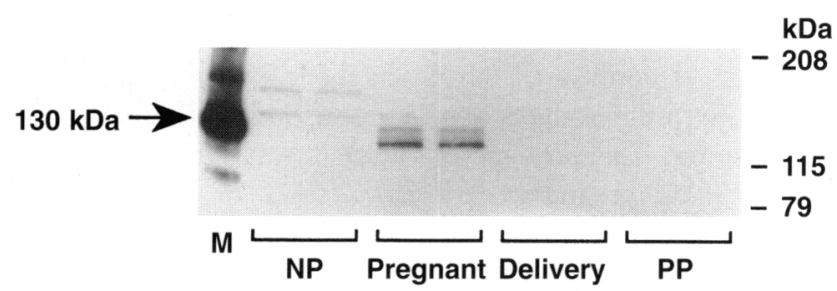

Fig. 3. Western blotting using a monoclonal antibody against mouse macrophage-nitric oxide synthase (NOS II) in the uterus from two representative nonpregnant rats during dioestrus (NP), and pregnant rats on day 18 of gestation, during delivery, and on day 1 postpartum (PP). M: cytosolic fraction from cytokine stimulated mouse macrophages. The antibody reacted with two protein bands at 125 and $130 \mathrm{kDa}$. Note that these protein bands are detectable only during pregnancy on day 18 of gestation.

\section{NOS II}

The monoclonal antibody to NOS II reacted with the appropriate band corresponding to the $130 \mathrm{kDa}$ protein from cytokine stimulated murine macrophage cell line, RAW264.7, but not with that of cerebellum or endothelial cells, indicating the specificity of this antibody to detect NOS II (Figs 3 and 4). In the uterine specimens obtained from days 16-22 of gestation, this antibody reacted with two major protein bands, one with a similar size $(130 \mathrm{kDa})$ to that from the macrophage cell line and the other slightly smaller in size ( $125 \mathrm{kDa}$ ). Many earlier studies indicated that the size of the NOS II isoform varied between $120 \mathrm{kDa}$ and $135 \mathrm{kDa}$. Although the reacted

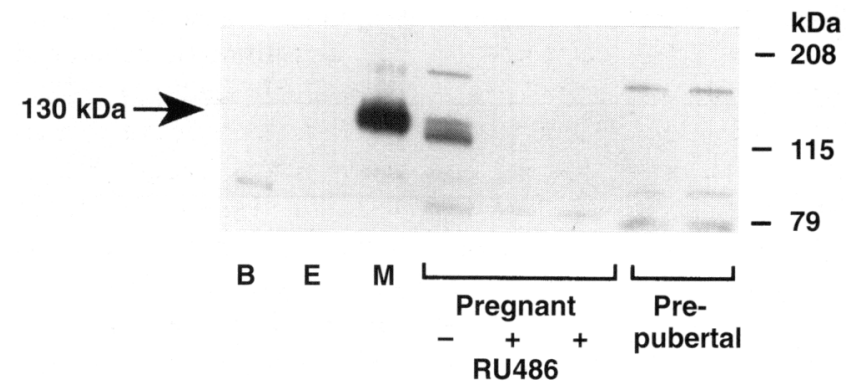

Fig. 4. Western immunoblotting for nitric oxide synthase II of proteins from cytokine-stimulated mouse macrophage cells (M), uterus from rats on day 18 of gestation with or without administration of antiprogesterone, RU486, and uterus from prepubertal rats. Note that this antibody did not react with proteins from either rat cerebellum (B) or human endothelial cells (E).

protein bands in the uterus range from $125 \mathrm{kDa}$ to $130 \mathrm{kDa}$, we analysed only the $130 \mathrm{kDa}$ band corresponding to the size of the positive control, for comparisons among different groups. The NOS II protein in the uterus is detectable predominantly during pregnancy (days 16-22 of gestation), and this was $518-726 \%$ relative to the amount of protein in the uterus from nonpregnant rats at dioestrus $(100 \%)$ and it declined markedly during delivery and day 1 postpartum (Table 1). NOS II was undetectable in the uterus on day 18 of gestation during RU486-induced preterm delivery (Fig. 4) and also undetectable in the uterus from prepubertal rats. These data indicate that the amount of NOS II is minimal in the nonpregnant state, is upregulated during pregnancy and is downregulated during term and preterm delivery.

\section{NOS III}

The antibody against NOS III isoenzyme reacted with a specific band at $140 \mathrm{kDa}$ from the membrane fraction of human endothelial cells, but not with that of cerebellum or macrophages, indicating the specificity of this antibody (Figs 5 and 6). A band at $140 \mathrm{kDa}$ corresponding to the size of NOS III protein was detectable in the uterus from nonpregnant rats and rats at all stages of gestation examined (Fig. 5); however, there were no significant changes in the amount of NOS III among different groups (Table 1). Furthermore, NOS III content of the uterus did not change during preterm delivery induced by RU486 (Fig. 6). In addition, the NOS III protein was present in the uterus of prepubertal rats (Fig. 6). These data indicate that NOS III protein content in the uterus is not regulated at gestation.

\section{Nitric oxide synthase activity in rat uterus during pregnancy and labour}

The NADPH-dependent conversion of L-arginine to i-citrulline was detectable in rat uterine tissues during pregnancy and delivery. The NADPH-sensitive NOS activity which is dependent upon $\mathrm{Ca}^{2+}$ was similar in rats during pregnancy and delivery (term and RU486-induced) (Table 2). However, the $\mathrm{Ca}^{2+}$-independent NOS activity in the uterus 
Table 1. Relative changes in the protein concentration of nitric oxide synthase (NOS) isoforms in rat uterus, measured as densitometric units of specific bands on western blots

\begin{tabular}{|c|c|c|c|c|c|c|c|c|}
\hline \multirow{2}{*}{$\begin{array}{l}\text { NOS } \\
\text { isoform }\end{array}$} & \multirow{2}{*}{$\begin{array}{c}\text { Non- } \\
\text { pregnant }\end{array}$} & \multicolumn{4}{|c|}{ Pregnant } & \multirow[b]{2}{*}{ Delivery } & \multirow{2}{*}{$\begin{array}{l}\text { Postpartum } \\
\text { day } 1\end{array}$} & \multirow{2}{*}{$\begin{array}{l}\text { RU486 } \\
\text { induced } \\
\text { preterm } \\
\text { labour }\end{array}$} \\
\hline & & Day 16 & Day 18 & Day 20 & Day 22 & & & \\
\hline NOS I & 100 & $10.3 \pm 1.5^{*}$ & $11.0 \pm 1.7^{*}$ & $10.2 \pm 1.5^{*}$ & $10.0 \pm 1.4^{*}$ & $9.5 \pm 2.3^{*}$ & $11.0 \pm 1.6^{*}$ & $9.5 \pm 2.2^{*}$ \\
\hline NOS II & 100 & $517.8 \pm 18.0^{*}$ & $726.3 \pm 29.2^{*}$ & $682.0 \pm 18.2^{*}$ & $561.0 \pm 25.0^{*}$ & $88.7 \pm 9.9$ & $96.8 \pm 8.4$ & $93.5 \pm 8.1$ \\
\hline NOS III & 100 & $90.8 \pm 10.9$ & $96.0 \pm 9.5$ & $92.3 \pm 10.2$ & $89.3 \pm 10.4$ & $91.3 \pm 14.4$ & $89.7 \pm 10.8$ & $97.0 \pm 8.4$ \\
\hline
\end{tabular}

Data are expressed as percentage change from nonpregnant animals. Values are means \pm SEM for six animals per group.

$* P<0.01$ versus nonpregnant animals by ANOVA.

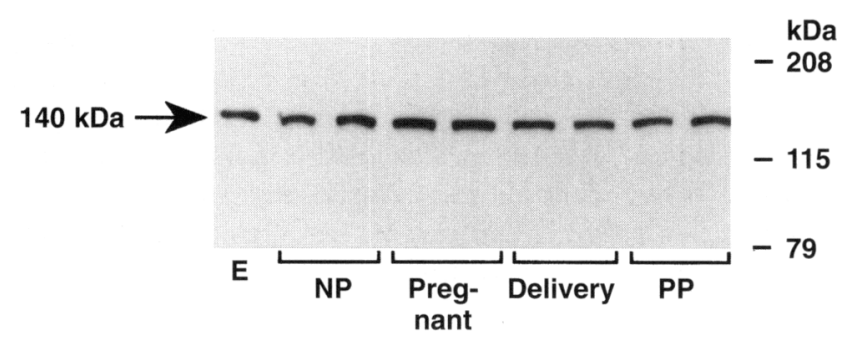

Fig. 5. Western blotting, using a monoclonal antibody against endothelial cell-nitric oxide synthase (NOS III), of proteins from the uterus of two representative nonpregnant rats during dioestrus (NP), and pregnant rats on day 18 of gestation, during delivery, or on day 1 postpartum (PP). E: human endothelial cells. The antibody reacted with a protein band at $140 \mathrm{kDa}$.

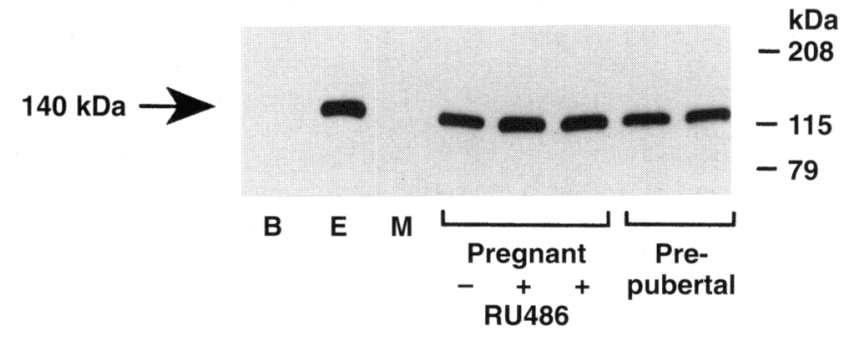

Fig. 6. Western immunoblotting for nitric oxide synthase III of proteins from human endothelial cells $(\mathrm{E})$, uterus from rats on day 18 of gestation with or without administration of antiprogesterone, RU486, and uterus from prepubertal rats. Note that this antibody did not react with proteins from either rat cerebellum (B) or cytokine stimulated mouse macrophages (M).

was significantly $(P<0.05)$ lower in animals during delivery at term or preterm (induced by RU486), than it was during pregnancy (on day 18 of gestation) (Table 2).

\section{Discussion}

Nitric oxide production in the rat uterus is upregulated during pregnancy and downregulated during delivery and it is postulated that increased endogenous NO production during pregnancy may play a role in maintaining uterine quiescence during gestation (Yallampalli et al., 1994a, b). In the present study, we
Table 2. Nitric oxide synthase activity (fmol citrulline $\mathrm{mg}^{-\mathrm{I}}$ protein $\min ^{-1}$ ) in uteri of rats during pregnancy and labour and antiprogesterone-treated rat uterus

\begin{tabular}{lcc}
\hline $\begin{array}{l}\text { Day of } \\
\text { pregnancy }\end{array}$ & $\begin{array}{c}\text { Calcium } \\
\text { dependence }\end{array}$ & $\begin{array}{c}\text { Calcium } \\
\text { independence }\end{array}$ \\
\hline Pregnant, day 18 & $80 \pm 13$ & $170 \pm 30$ \\
Spontaneous labour & $100 \pm 30$ & $20 \pm 8^{*}$ \\
RU486-induced labour & $120 \pm 20$ & $70 \pm 30^{*}$ \\
\hline
\end{tabular}

Enzyme activity was measured using the $\left[{ }^{3} \mathrm{H}\right]$ arginine to $\left[{ }^{3} \mathrm{H}\right] \mathrm{citrulline}$ conversion assay. The decrease in calcium-independent NOS activity during labour, both spontaneous and RU486-induced, was significant $\left({ }^{*} P<0.05\right)$ compared with that during pregnancy $(n=4)$.

examined isoform(s) of NOS in the rat uterus that may contribute to the changes in NO production at different stages of gestation. The protein for NOS II was abundant in the uterus during pregnancy, on days 16-22 of gestation, and was undetectable during spontaneous labour at term, RU486induced labour at preterm, and in nonpregnant, adult or prepubertal rats. The changes in the NOS II content associated with pregnancy and delivery parallel the changes in $\mathrm{Ca}^{2+}$. independent NOS activity and suggest that NOS II may be the major contributing enzyme for variation in $\mathrm{NO}$ production during pregnancy and delivery. However, the content of NOS III in the uterus was unchanged during the different stages of gestation examined. NOS I was undetectable during pregnancy although it was present in nonpregnant rats. These studies indicate that increased NOS II protein is responsible, at least in part, for the increased NO production during pregnancy and therefore for uterine quiescence during pregnancy, and a decrease in this isoform is associated with the decrease in $\mathrm{NO}$ activity during delivery.

The major finding is that NOS II protein in the rat uterus is extremely low during nonpregnant stages and is substantially increased during pregnancy and is decreased during both spontaneous delivery at term and RU486-induced preterm delivery. This is consistent with changes in $\mathrm{Ca}^{2+}$-independent NOS activity in these animals. Natuzzi et al. (1993) reported that calcium-independent NOS activity (a well known characteristic of NOS II) in the rat uterus was maximum during pregnancy and is decreased substantially during spontaneous 
delivery and postpartum. In addition, using rabbit decidual tissues, Sladek et al. (1993) showed that the NOS activity, which has the characteristics of an inducible isoform of the enzyme, is substantially lower at the end of gestation. These studies, together with the present study, provide evidence that the uterine NOS II protein is increased during pregnancy and this increased protein may be responsible for increased NOS activity and thus for uterine quiescence. Although RU486induced preterm labour has been established for many years, our data demonstrated for the first time that RU486-induced preterm labour was associated with substantially decreased NOS II protein, indicating that the expression of NOS II may be, at least partially, regulated by progesterone.

NOS III isoform may also contribute to the total NOS activity in the uterus, since NOS III protein was readily detectable in the rat uterus at various stages examined. However, there were no significant changes either in NOS III protein content or in $\mathrm{Ca}^{2+}$-dependent activity in the rat uterus associated with pregnancy and delivery, indicating that this isoform may not be primarily responsible for the changes in total NOS activity. This conclusion is further supported by the studies of Natuzzi et al. (1993) and Sladek et al. (1993), in which there were no significant pregnancy-associated changes in $\mathrm{Ca}^{2+}$-dependent NOS activity. Therefore, we propose that the relative contribution of the NOS III isoform to the pregnancy associated changes in total NOS activity in the uterus is marginal.

In contrast to NOS II and NOS III, NOS I protein was undetectable in the rat uterus during pregnancy and, therefore, the relative contribution of NOS I for total NOS activity during pregnancy is also negligible. It is interesting to note that NOS I protein was detectable in the uterus of prepubertal rats and in adult rats during the nonpregnant stage. This observation is further supported by a recent report that uteri from non-pregnant rats contain nerve-associated NOS activity (Shew et al., 1993). The decline in NOS I during pregnancy could be attributed to the degeneration of nerves in the uterus during this period (Stjernquist and Sjöberg, 1994). The cellular location of different isoforms of NOS in the uterus is uncertain at present, and requires immunohistochemical studies.

The monoclonal antibodies to NOS I, II, and III reacted with proteins with molecular weights specific to the corresponding isoforms. The antibodies to both NOS II and III did not crossreact with other isoforms. However, NOS I antibody reacted with a protein from macrophages at $130 \mathrm{kDa}$, in addition to NOS I (protein at $155 \mathrm{kDa}$ obtained from rat cerebellum). On the basis of the molecular size of the protein reacted with a specific antibody and crossreactivity, the data on changes in the content of different NOS isoforms, NOS I, II and III in the uterus during pregnancy and labour, are valid.

The mechanisms responsible for an increase during pregnancy and a decrease during labour in the NOS II protein in the uterus are unclear at present. It is unclear from the present study exactly when during pregnancy these changes in NOS II actually occur in the uterus. It is also not clear whether the changes in NOS II protein are modulated by female sex steroid hormones, although studies indicate that antiprogestins reduce NOS II protein in the rat uterus. It has been reported that NOS activity in several maternal tissues increases early in pregnancy
(Weiner et al., 1994) and that several types of uterine cells, myometrial mast cells and endometrial epithelial cells, produce NOS II, the expression of this enzyme appearing to be modulated by ovarian steroid hormones (Huang et al., 1995). Cytokines induce NOS II protein in a variety of tissues and several studies have reported changes in a variety of cytokines associated with pregnancy (Hunt, 1989). Notwithstanding the type and the timing of the stimulus for the increase and decline in NOS II in the uterus, the changes in this isoform and thus NO production in this tissue may play a significant role in the maintenance of uterine quiescence during pregnancy and initiation of labour.

In summary, we demonstrated that all the three isoforms of NOS: NOS I, NOS II and NOS III are detectable in the rat uterus by western immunoblotting. The NOS II protein and $\mathrm{Ca}^{2+}$-independent NOS activity is increased during pregnancy and decreased during labour (both at term and preterm) without changes in NOS III content, while NOS I protein was undetectable during gestation. Taken together with our previous observations (Yallampalli et al., 1993, 1994a, b), present studies suggest that NOS II could play a significant role in the generation of $\mathrm{NO}$ in the uterus and thus in the maintenance of uterine quiescence during pregnancy.

This work was supported by a grant from National Institutes of Health, RO1 HD 30273, to C. Yallampalli.

\section{References}

Brown JF, Tepperman BL, Hanson PJ, Whittle BJR and Moncada S (1992) Differential distribution of nitric oxide synthase between cell fractions isolated from the rat gastric mycosa Biochemical and Biophysical Research Communications 184 680-685

Bush P, Gonzales N and Ignarro L (1992) Biosynthesis of nitric oxide and citrulline from $\mathrm{L}$-arginine by constitutive nitric oxide synthase present in rabbit corpus cavernosum Biochemical and Biophysical Research Communications 186 308-314

Huang J, Roby KF, Pace JL, Russell SW and Hunt JS (1995) Cellular localization and hormonal regulation of inducible nitric oxide synthase in cycling mouse uterus Journal of Lexkocyte Biology 57 27-35

Hunt JS (1989) Macrophages as pivotal regulatory cells Journal of Reproductive Immunology 16 1-17

Jackson WF and Busse R (1991) Elevated guanosine $3^{\prime}-5^{\prime}$-cyclic monophosphate mediates the depression of nitro-vasodilator reactivity in endothelium-intact blood vessels Archives of Pharmacology 344 345-350

Marletta MA (1993) Nitric oxide synthase structure and mechanism Journal of Biological Chemistry 268 12 231-12 234

Moncada SR, Palmer MG and Higgs EA (1991) Nitric oxide: physiology, pathophysiology and pharmacology Pharmacological Reviews 43 109-142

Natuzzi ES, Ursell PC, Harrison M, Buscher C and Riemer RK (1993) Nitric oxide synthase activity in the pregnant uterus decreases at parturition Biochemical and Biophysical Research Communications 194 1-8

North AJ, Star RA, Brannon TS, Ujiie K, Wells LB, Lowensten CJ, Snyder SH and Shaul PW (1994) Nitric oxide synthase type I and type III gene expression are developmentally regulated in rat lung American Journal of Physiology 266 L635-L641

Sessa WC (1994) The nitric oxide synthase family of proteins Journal of Vascular Research 31 131-143

Shew RL, Papka RE, McNeill DL and Yee JA (1993) NADPH-diaphorase-positive nerves and the role of nitric oxide in CGRP relaxation of uterine contraction Peptides 14 637-641

Sladek SM, Regenstein AC, Lykins D and Roberts JM (1993) Nitric oxide synthase activity in pregnant rabbit uterus decreases on the last day of pregnancy American Journal of Obstetrics and Gynecology 169 1285-1291 
Stjernquist M and Sjöberg N-O (1994) Neurotransmitters in the myometrium. In The Uterus pp 193-229 Eds T Chard and JG Grudzinskas. Cambridge University Press, Cambridge

Weiner CP, Knowles RG and Moncada S (1994) Induction of nitric oxide synthesis early in pregnancy American Journal of Obstetrics and Gynecology $171838-843$

Yallampalli C, Garfield RE, and Byam-Smith M (1993) Nitric oxide inhibits uterine contractility during pregnancy but not during delivery Endocrinology 133 1899-1902
Yallampalli C, Byam-Smith M, Nelson SO and Garfield RE (1994a) Steroid hormones modulate the production of nitric oxide and cGMP in the rat uterus Endocrinology 134 1971-1974

Yallampalli C, Izumi H, Byam-Smith M and Garfield RE (1994b) An L-argininenitric oxide-cyclic guanosine monophosphate system exists in the uterus and inhibits contractility during pregnancy American Journal of Obstetrics and Gynecology 170 175-185 